\title{
Stagnate to Extensive: The Design of Capital City Development in Coastal Archipelago Raja Ampat
}

\author{
Sri Astuti \\ Research Institute for Housing Settlements, Ministry of Public Works, Indonesia
}

\begin{abstract}
This discussion of Raja Ampat case, a subdivision of West Papua province, is related to the global warming issue where small islands will be narrowed as a result of sea level rise. Furthermore, it is related to autonomy regulations where each municipality and district has their own policy. The capital of Raja Ampat District in the east of Indonesia is developed from traditional place into central urban area. Raja Ampat, a naturally beautiful island, is located in a remote area famous for its diving spot for foreign tourists, amazing underwater life, bird watching, and to experience a traditional lifestyle with specific tropical fauna and flora. The problem is how to develop a city which needs to be in a stagnant extensive phase but neither in vertical nor horizontal development to protect forest as conservation area due to limited land area. Identification and design methods used in this research is to develop settlement in Raja Ampat archipelago area which has around 610 large and small islands, atoll, and have $4.860 \mathrm{~km}$ shoreline with only 34 islands inhabited. The urban design for this archipelago of 1:6 ratios of land and ocean needs to be different, since it is dominated by water. With the limited land area resources, the development needs to be focused on the ocean area by optimizing land area.
\end{abstract}

Key words: Coastal area, sustainable design, stagnant to extensive, archipelago.

\section{Introduction}

Located in the eastern part of Indonesia, Raja Ampat (Fig. 1) regency officially became an autonomous region in 12 April 2003, based on the act no. 26/2002. This district has a total area of approximately 46,296.000 square kilometres, with 85 percent ocean, and the remaining 6,000 square kilometres is mainland. It has around 610 large and small islands with four of main islands namely Misool, Salawati, Batanta, and Waigeo. From all islands, only 35 are inhabited while others are uninhabited and unnamed.

Its remote location is the main constraint in developing a new town in this area. It also has a geological characteristic with unstable condition due to approximately 1200 tectonic earthquake that happened during 1973 until 2004. This is a conserved area of forest, birds and wildlife, marine and underwater life. The total of this conservation area is 483.500 Ha from six different locations as seen in Table 1.

Corresponding author: Sri Astuti, $\mathrm{PhD}$, research fields: human settlements. E-mail: sasti@bdg.centrin.net.id.
Table 1 National conservation area in Raja Ampat Regency.

\begin{tabular}{|c|l|c|}
\hline No & Name of protected/conservation area & $\begin{array}{c}\text { Width area } \\
(\mathrm{Ha})\end{array}$ \\
\hline 1. & $\begin{array}{l}\text { Nature conservation of west Waigeo } \\
\text { island }\end{array}$ & 153.000 \\
\hline 2. & $\begin{array}{l}\text { Nature conservation of east Waigeo } \\
\text { island }\end{array}$ & 119.500 \\
\hline 3. & $\begin{array}{l}\text { Nature conservation of west Batanta } \\
\text { island }\end{array}$ & 10.000 \\
\hline 4. & $\begin{array}{l}\text { Nature conservation of north Salawati } \\
\text { island }\end{array}$ & 57.000 \\
\hline 5. & $\begin{array}{l}\text { Nature conservation of south Misool } \\
\text { island }\end{array}$ & 84.000 \\
\hline 6. & $\begin{array}{l}\text { Fauna and flora conservation of Raja } \\
\text { Ampat ocean and islands }\end{array}$ & 60.000 \\
\hline & \multicolumn{1}{|c}{ TOTAL } & 483.500 \\
\hline
\end{tabular}

These constrains caused limitation in developing Kampong Waisai as the capital city of Raja Ampat regency. Kampong Waisai in south Waigeo district has now become the capital city of Raja Ampat regency and developed since 2004. After it has developed into a new principal city, it becomes the activity orientation in Raja Ampat both as a central government administration and centre of economic and settlements activities. Its topographic conditions of limited 


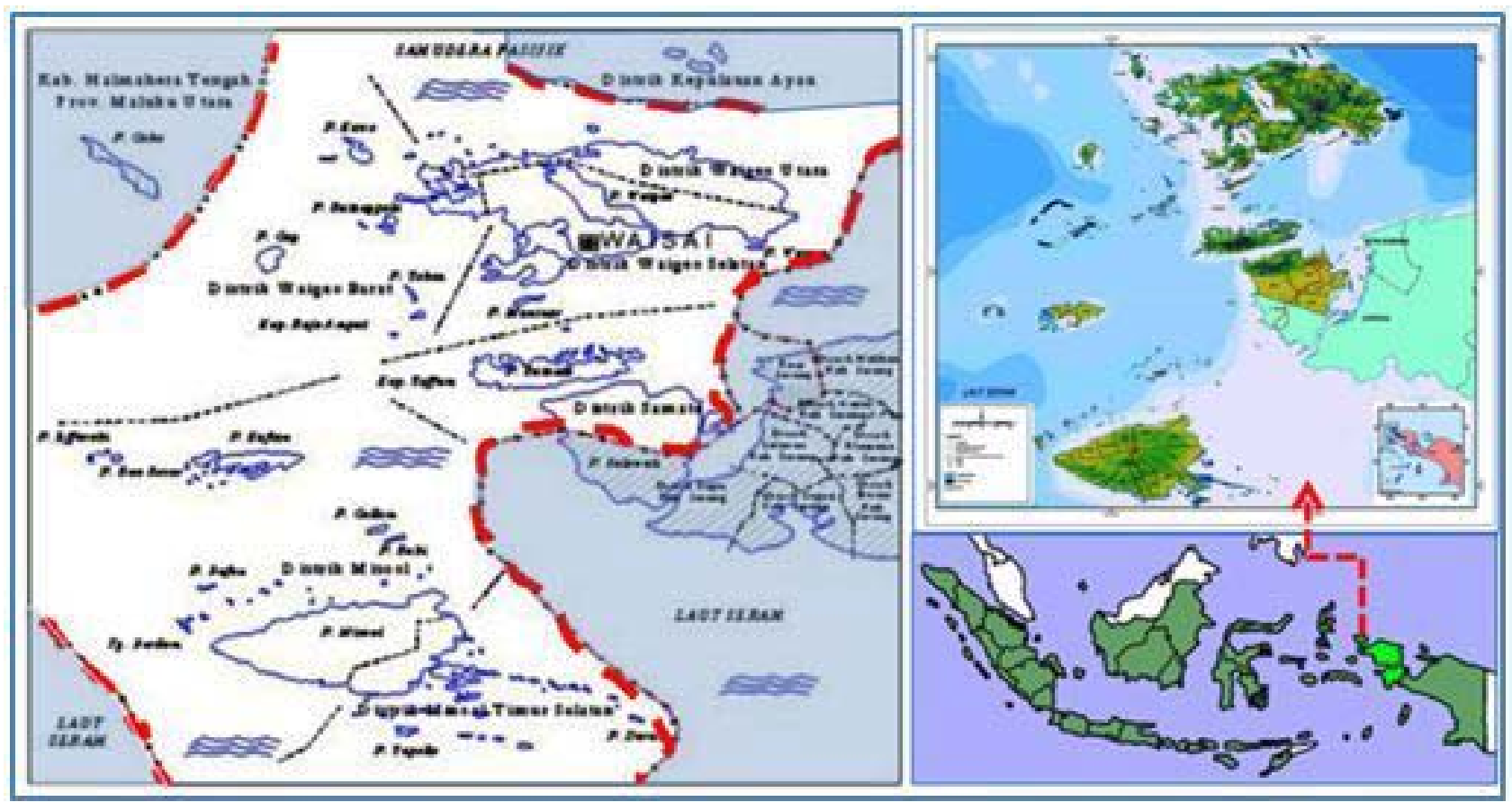

Fig. 1 Raja Ampat archipelago.

appropriate lands slope for settlements encourage the process of cutting steep hill for development of infrastructure and activity support to the city. These cutting and opening the hill caused an ecosystem changes and must be taken care seriously to avoid negative impacts of disasters; such as landslides, flooding and erosion. The objective of this study is to enhance the capacity of the environment as a result of ecosystem changes from fauna and floras into human settlements.

\section{Comparative Study between Kampong Naga and Waisai}

Kampong Naga is successful in integrating works and settlement systems and maintaining their culture. It is a fertile valley area of 1.5 hectares and is divided into forest, river, rice field area, and local villages. Each has its own boundaries. For example, dwelling area may not be built on rice field, and vice versa. This kampong (village) has 111 buildings, consisting of 108 houses, 1 meeting hall (bale patemon), 1 mosque, and 1 rice barn. The number of buildings and houses cannot be increased again. Mosque, meeting hall and the barn are placed in parallel, facing east-west. At the front, there is an open space used for traditional ceremonies. In front of a large mosque there is kentongan (drum made from wood to sound an alarm or inform something), used to be announce something to the mass; a praying time or if there is a danger.

The other 108 family houses must face north-south. Because this area has a lot of termites, the house is made in stage model, which is elevated about $50 \mathrm{~cm}$ above the ground. Walls are made of plaited bamboo or raw wood chip, or painted with white lime. In addition to colour, white chalk is useful to protect the walls from the termites attack. The roofs are made from fibre palm (ijuk), reed, or thatch palm leaves. There are three types of forests; forest restrictions, forest that people could work on, and forest reserves. Forest restriction is a forest prohibited from entering and located on the west and east of kampong Naga. In the west, there are ancestral graves that should only be entered by traditional leaders at the ceremony while the east forest adjacent to the Ciwulan River is restricted to anyone. Forest that people could work on is owned by each person and there are many types of wood planted 
(Sengon, Meranti, Ganitri and bamboo) and cultivated by chilli, spices, corn, and peanut as a mixture between wood plants.

Forest reserves are prohibited for personal use and can only be used communal usage such as the needs to build a bamboo fences. With these local wisdoms to keep the forest, it keeps Kampong Naga (Fig. 2) from floods, landslides, drought and it also offers continuous spring water. Those restrictions are used to keep the balance of land and population, with the consequence that many descendants of Kampong Naga must live outside the village of Kampong Naga areas. However, they still participate in activities, customs and ceremonies. Living in harmony with nature, is not only slogan but it is a real life. This case is a type of stagnate typology to hold the area in proportional ratio between occupation and population. It also shows how each zoning area functioned between forest, field rise, and settlement. This case is reliable if applied in rural area and it can happen only if people still hold the strong belief on the balance of harmony between life and nature.

Waisai was originally a village, with a strong belief to maintain the preservation of its nature. The changes from sub district to capital district have occurred in administrative that consequently followed by physical development. In the purpose of sustainable development, it must have a balance between life and nature to maintain the wealthy fauna and flora in both of their sea and land. The area of capital city Waisai is $1100 \mathrm{Ha}$ and used for infrastructures such as road bridges as well as social economic facilities like religious service, market, ports, health and education building. The boundary of the central city are hilly forest in the north, river and hills in the east, Dampier strait in the south and mountainous forest and Dampier strait in the west as seen in Fig. 3. Government offices are also built to serve administrative function. In 2006, a number of people living in Waisai city increased to a total of around 4168 people.

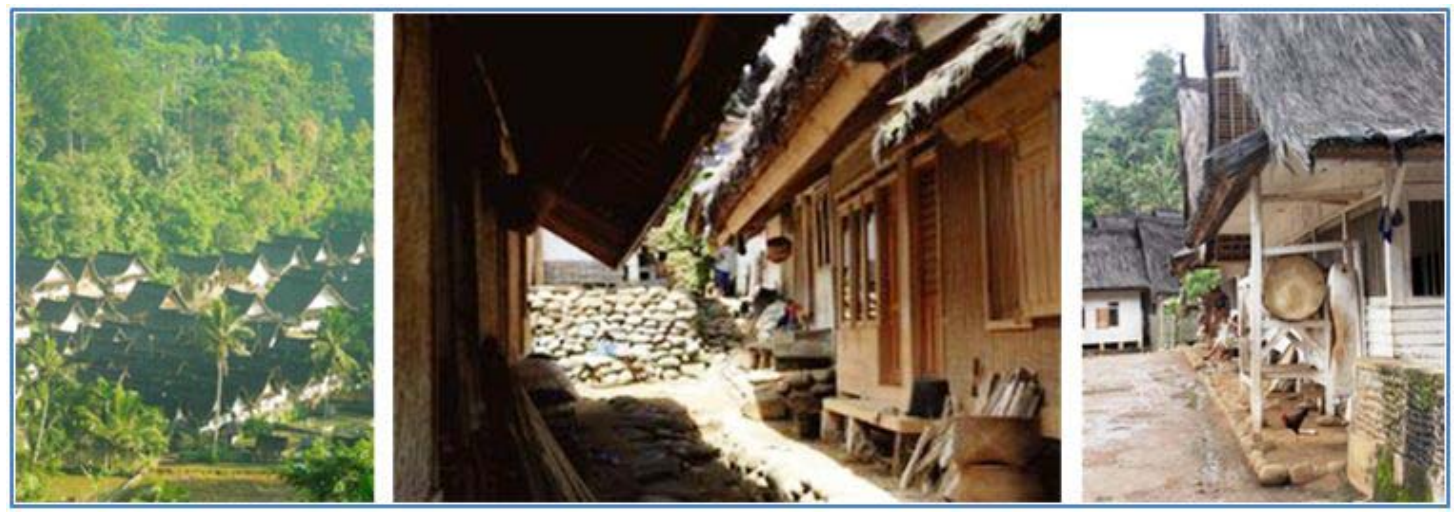

Fig. 2 Kampong Naga.

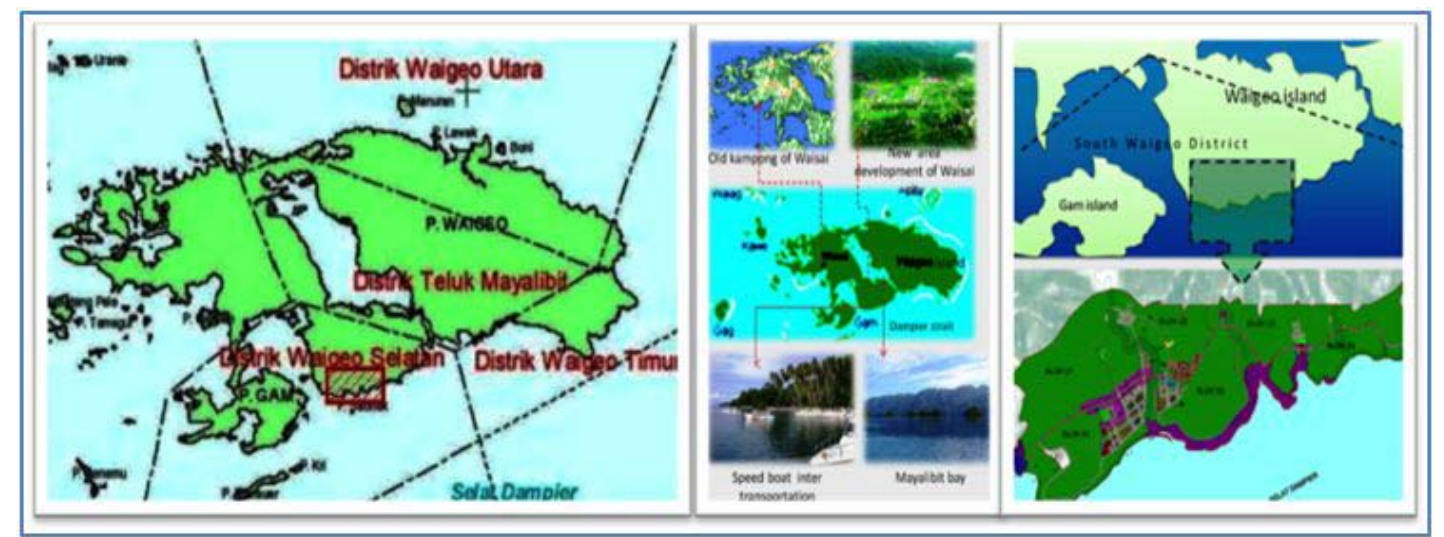

Fig. 3 Detail planning of Waisai City. 


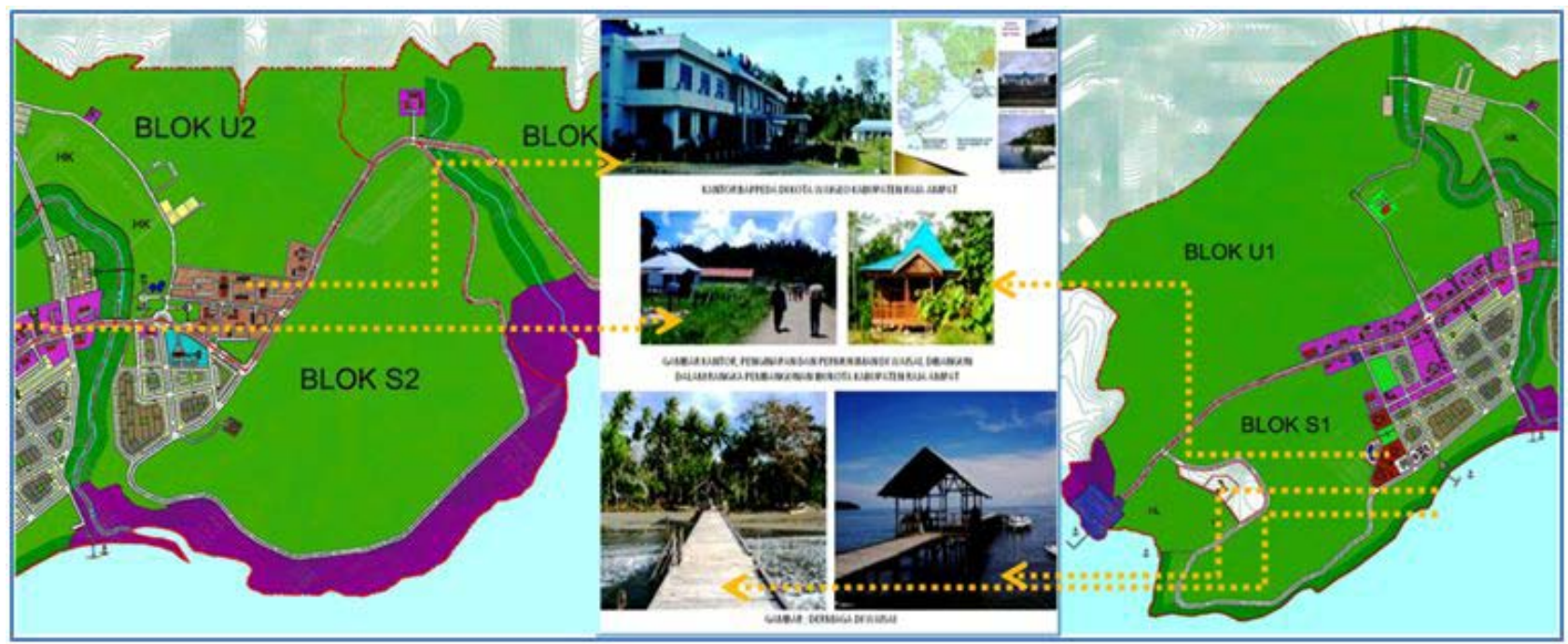

Fig. 4 Existing condition of Waisai city, shown above, an official building, road, resort, bay.

\section{Applying Garden City Concept in Waisai} City

Garden City is part of a larger development, which proposed a city parks around the city centre with connected and shared service or entertainment facilities. This idea requires the establishment of city-suburban new town, limited in size, surrounded by a green belt of agricultural land. These cities will grow independently, managed and financed by city residents who have economic interests there. Howard's draft requires land area of 6,000 acre $\left(1\right.$ acre $=4540 \mathrm{~m}^{2}$ ), built for 1000 to 30,000 inhabitants (density 30 persons/acre) and additional 2000 people to harvest 5000 acre of agricultural land. The city is also in a circle form with its boulevard width of 120 feet (36.6 meters), and planted by trees which divide the city in six sectors (Fig. 5).

In line with the establishment of Waisai as the capital of district, as prepared in the Details Plan of Spatial City Waisai in 2004 with a total area of 600 Ha. However, because it does not meet the needs, the space is widening into approximately $1100 \mathrm{Ha}$. Since this is a conservation area, the development concept of Waisai city needs to be oriented to the sustainable development concept based on the environmental resources as seen in Fig. 6.
In relation to the Waisai city, this concept of Garden City will be applied with attention to the function, potential and constraint of the area. According to Shirvani (1985), there are eight urban design elements included; land use, building form and mass, circulation and parking, open space, pedestrian, signage, and preservation. Land use in Waisai focuses on local condition as well as the new administrative function, while the physical aspects of building form and mass are specifically allowed only maximum of two storey heights and 60 percent building coverage. Buildings need to be low enough to avoid the birds from the risk of rushing into the building with glass facade finishing. Circulation and motorcycle and car park also become an essential part of social life in today and future trends. However, these will need to be put on hold to keep the fauna and flora habitat in this area; otherwise it will lose its potential as a nature area.

In relation to open space, a balance between hard space and soft space such as roads, sidewalks, parks, and recreational spaces needs to be developed to keep the existing natural condition of Waisai as a new urban area. Pedestrian holds the most important role because for the comfort of reaching a certain distance will encourage someone to go on foot rather than by car. Limitation on the road usage for vehicles is needed to maintain good air pollution and noise. Activity support including all the uses and activities that help 


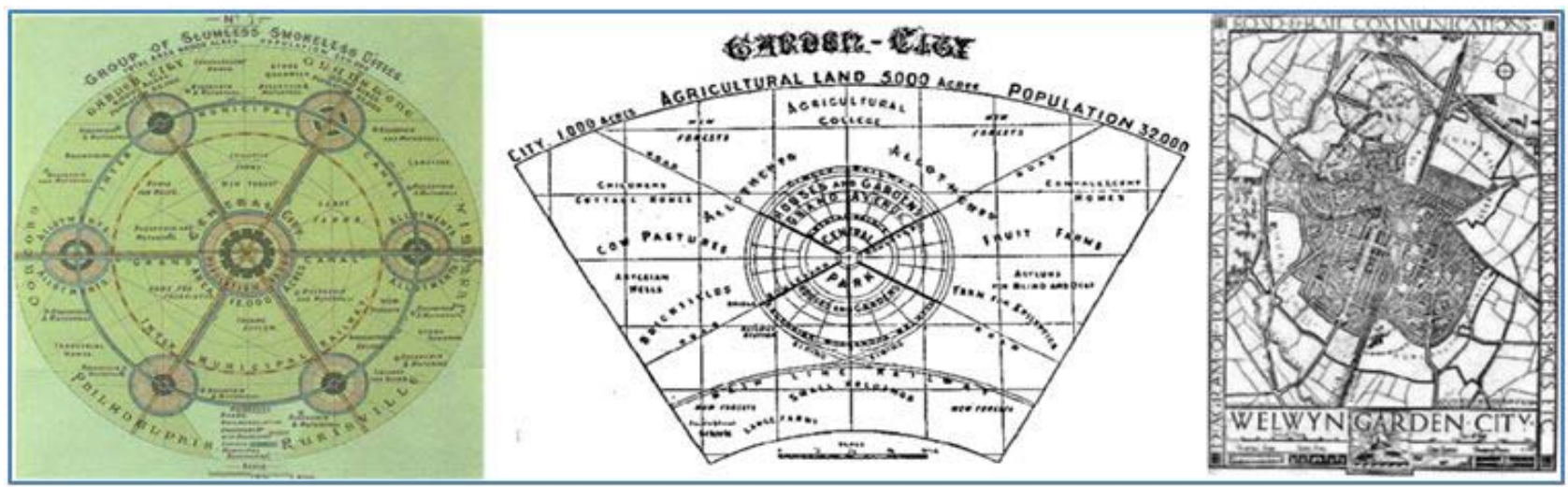

Fig. 5 Concept of Garden city by Howard.

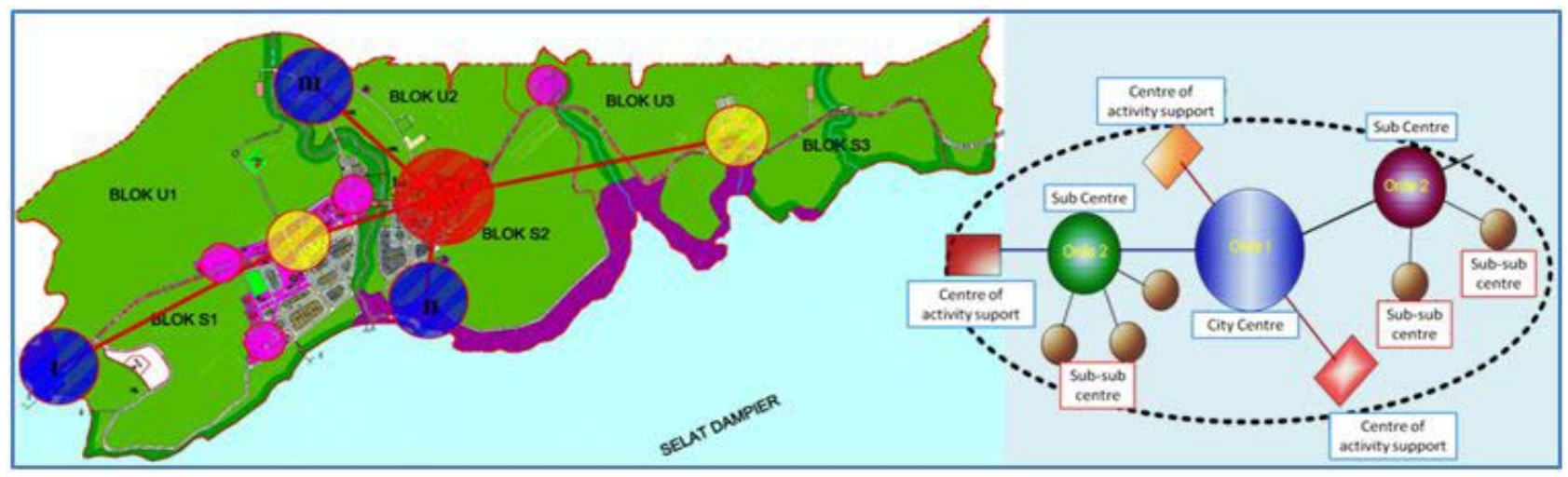

Fig. 6 Planning concept of Waisai city (Detail Design of Waisai).

strengthening activities in urban public spaces have always been complementary to each other. Signage, both form and placement of signs, have become increasingly important as visual elements in this cities. This includes placement, colour and dimensions of signage.

In this case, preservation are not only made to traditional buildings, or historic buildings, but the most important is the conservation of nature, especially in this area of fauna and flora environment which is very important. According to the Details Plan of Spatial City Waisai, the block S2 are developed for settlement, harbour, commercial area, office and green area, while block S3 is used for reserve area.

The spatial planning of new urban area used on Waisai development shows that this area will be developed into the formal housing estate that suitable for migrant labour coming to this area. There are a number of people already live in this island with non-formal job for years as farmers and fisherman.
They have a traditional way to preserve forest and sea products called sasi. According to the Details Plan of Spatial City Waisai that officially used as a direction on development of Waisai city, there is an inadequate spatial planning for local people who lived in their vernacular housing type that satisfy their livelihood. Traditionally, the native people are the owner of this area known as community land or hak ulayat on this island.

If we analyze from the activities and positions towards the safety of disaster, flood, earthquake, tsunami, and landslide, the safe and proper place to developed for vernacular spatial planning is in the S3 block; the yellow area as seen on the Fig. 7. According to the concept of Garden City as the basic concept in Waisai Details Plan, there is a few problems in developing this area especially that this is a conservation area, with the road is more appropriate by using pedestrian way instead of by car or motorcycle transportation. Considering the hot climate of this area, 
shadows from trees or shelter protection is important to gain thermal comfort. The example of pedestrian way suitable for this Waisai city area is shown in Fig. 8.

\section{The Concept of S3 Block}

Space use pattern for seaside according to land allocation in macro structure are patterns including non permanent dwelling on the water zone, fish mart, processing zone, docks zone, and permanent dwelling zone. Micro structure of fishermen area is similar as the other part of Waisai that has two storey maximum height, 60 percent building coverage, and pedestrian use as much as possible (Fig. 9).

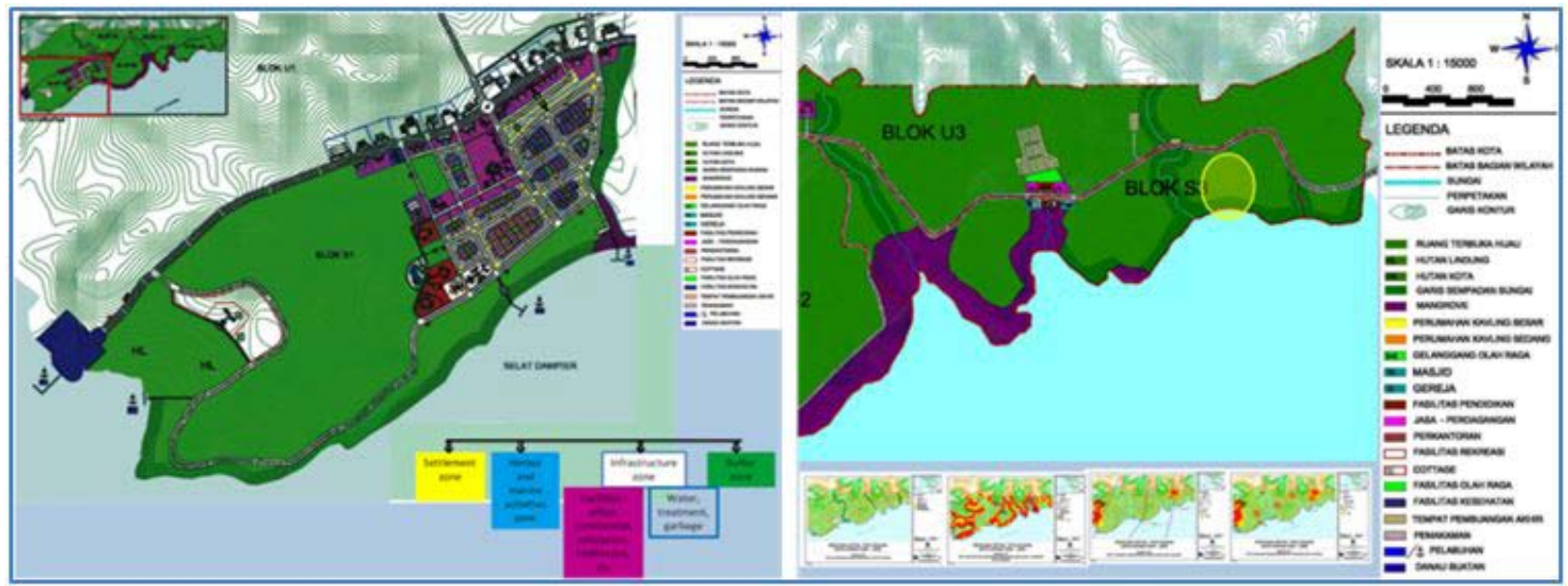

Fig. 7 Block S2 and Block S3.
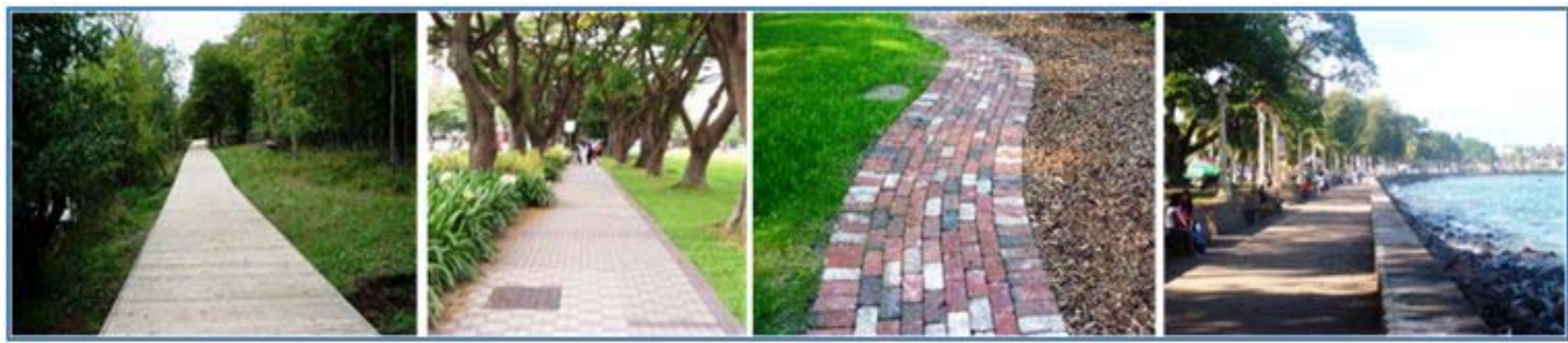

Fig. 8 Pedestrian way suitable for Waisai new urban area.

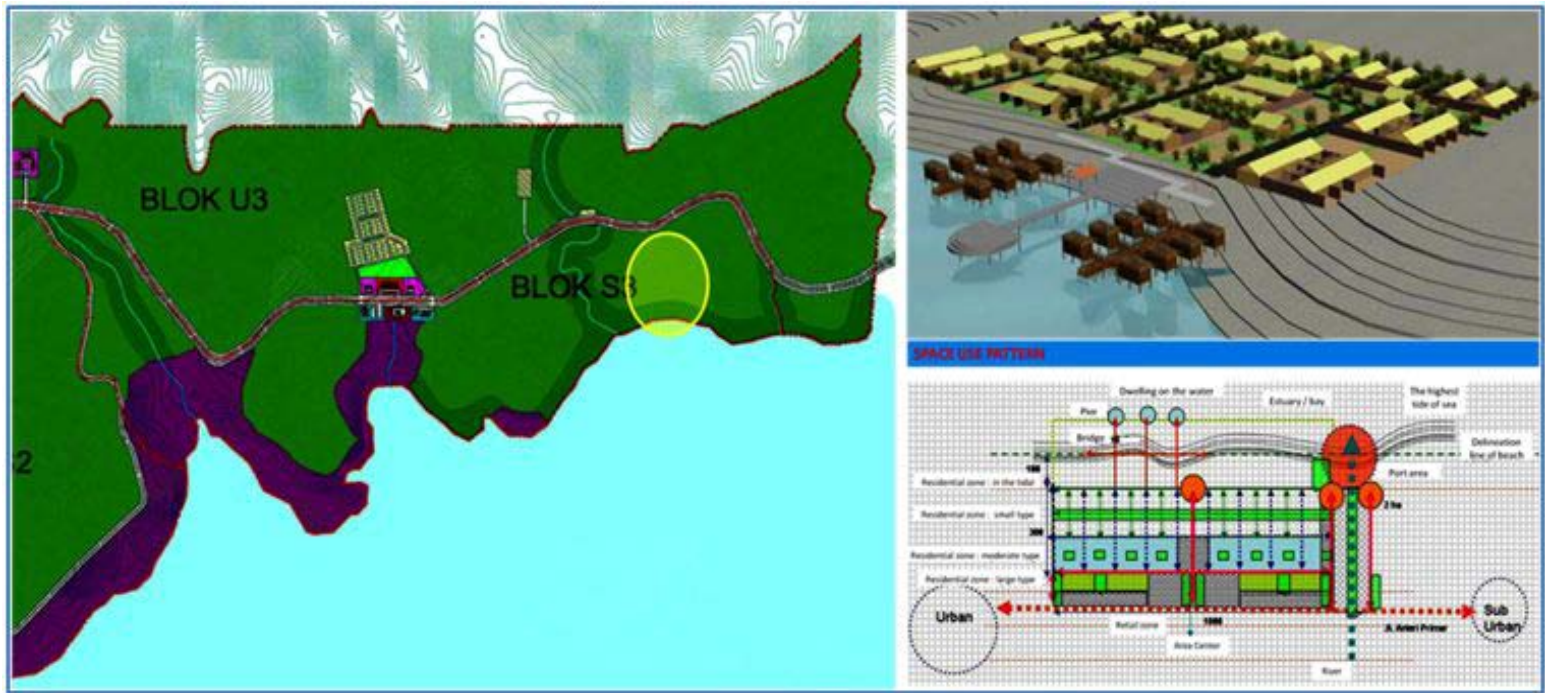

Fig. 9 Space use pattern of settlement in seaside. 


\section{Conclusion}

Waisai is a part of conservation area that should be maintained in spaciousness without reducing the protected forest and the inhabitant living in this area. Forest conservation, including fauna, flora and underwater biology has a high value that need to be protected from destruction activity caused by new city development. To maintain the habitat of flora and fauna on land and sea, the strict settings regarding building heights, size of the city, and activities that can be done in this area becomes very important. Access by foot is one way to reduce air pollution. To maintain the controlled development of the region, there are the needs of provision of housing for migrant workers and indigenous fishermen and farmers. In this case, the location of block S3 is suitable to be developed as a residential area safe for fishermen. To avoid extensive use of land in forest conservation, therefore, the micro region is set with a maximum building height of two floors, and building coverage of $60 \%$, also the number of people living in must be constant.

\section{References}

[1] Aditya W. Fitrianto, “City Walk” ruang terbuka alternative, Jakarta, Kompas, 7th Aug., 2005.

[2] Alan B. Jacobs, The Great Streets, New York, MIT Press, 1993.
[3] C. Alexander, A Pattern Language, New York, Oxford University Press, 1977.

[4] S. Astuti, Conflict of space use in the commercial area: A view from space use in five cities in Indonesia, Paper presented at the 3rd Great Asian Streets Symposium: A Public Forum of Asian Urban Design, Theme 2004: Street, Urban Space and Representation, National University Singapore, Dec. 6-7, 2004.

[5] Bandung Tourism Information Centre, Kampong Naga, available online at: http://www.dieny-yusuf.com/ 2007/03/02/kampung-naga/.

[6] Dirjen Cipta Karya Departemen Pekerjaan Umum, Pedoman Permukiman Nelayan, unpublished, 2007.

[7] E. Howard, Garden cities of tomorrow, available online at: http://www.library.cornell.edu/Reps/DOCS/howard.html.

[8] Pemerintah Kabupaten Raja Ampat, Rencana Detail Tata Ruang Kota Waisai, Ibu Kota Kabupaten Raja Ampat 2007-2026, unpublished, 2006.

[9] Pemerintah Kabupaten Raja Ampat, Kampung Waisai, available online at: http://www.rajaampatkab.go.id.

[10] Pusat Litbang Permukiman, Laporan Final, Pengembangan rumah dan lingkungan sehat untuk masyarakat tradisional tepi air, unpublished, 2008.

[11] A. Shirvani, The Urban Design Process, New York, Van Nostrand Reinhold Co., 1985.

[12] Peter Hall, Cities of Tomorrow, Third edition, Blackwell publishing, 2001. 